\title{
PENGARUH PERBANDINGAN KENTANG KUKUS DAN TEPUNG KACANG HIJAU (Phaseolus radiatus L.) TERHADAP KARAKTERISTIK FLAKES
}

\author{
The Effect of Steamed Potatoes and Green Bean Flour (Phaseolus radiatus L.) Ratio on The \\ Characteristics of Flakes
}

\author{
Lina Nindyawati ${ }^{1)}$, Putu Timur Ina ${ }^{2)}$, Anak Agung Istri Sri Wiadnyani' ${ }^{2)}$ \\ ${ }^{1)}$ Mahasiswa Program Studi Ilmu dan Teknologi Pangan, Fakultas Teknologi Pertanian, Unud \\ ${ }^{2)}$ Dosen Program Studi Ilmu dan Teknologi Pangan, Fakultas Teknologi Pertanian, Unud \\ Kampus Bukit Jimbaran, Badung-Bali
}

\begin{abstract}
This study aims to determine the effect of steamed potatoes and green bean flour on the characteristics of flakes, and to know the right ratio of steamed potatoes and green bean flour which produced flakes with the best characteristics. The was used in this research completely randomized design with the treatment ratio of steamed potatoes and green bean flour, which consists of 6 levels such as: $35 \%: 65 \%, 40 \%: 60 \%, 45 \%: 55 \%$, $50 \%: 50 \%, 55 \%: 45 \%, 60 \%: 40 \%$. The treatment was repeated 3 times to obtained 18 units of the experiment. The data were analysed by variance analysis and if the treatment had an effect on the variable then continued with Duncan test. The result showed steamed potatoes and green bean flour ratio had a significant effect on water content, ash content, fat content, protein content, carbohydrate content, color (hedonic), aroma (hedonic), texture (hedonic and scoring), taste (hedonic) and overall acceptance (hedonic). Ratio of 35\% steamed potatoes and $65 \%$ green bean flour produced flakes with the best characteristics, with $2.41 \%$ water content, $4.57 \%$ ash content, $19.16 \%$ protein content, $10.20 \%$ fat content, $63.66 \%$ carbohydrate content, color liked, aroma liked, texture crunchy and liked, taste netral and overall acceptance rather liked.
\end{abstract}

Keywords : steamed potatoes, green bean flour, flakes

\section{PENDAHULUAN}

Saat ini, pola pikir dan pola hidup masyarakat telah mengalami perubahan yang semakin praktis. Seiring dengan perubahan tersebut secara tidak langsung telah mengubah pola konsumsi pangan masyarakat yang cenderung menuntut kepraktisan, baik dari segi pembuatan maupun penyajian tanpa mengurangi pemenuhan kebutuhan akan zat gizi yang diperlukan oleh tubuh. Salah satu makanan yang praktis dan dapat memenuhi kebutuhan gizi adalah flakes. Menurut Paramita dan Widya (2015), Flakes merupakan makanan praktis pengganti sarapan terbuat dari biji-bijian atau serealia. Awalnya, flakes dibuat dari biji jagung utuh yang dikenal dengan nama corn flakes, namun pada saat ini telah dikembangkan inovasi dalam pengolahan flakes. Flakes merupakan salah satu bentuk dari produk pangan yang menggunakan bahan pangan serealia seperti beras, gandum, jagung dan umbi-umbian (Anggara et al., 2011 dalam Papunas et al., 2013).

Upaya diversifikasi pangan penting dilakukan untuk menggali potensi bahanbahan pangan lokal yang ada serta untuk meningkatkan keanekaragaman dan keseimbangan komposisi pangan yang dikonsumsi sehingga kualitas gizi juga akan

*Korespondensi Penulis:

Email: linanindya27@gmail.com ${ }^{1)}$ 
meningkat. Salah satu bahan pangan lokal yang banyak dan perlu dikembangkan di Indonesia adalah umbi-umbian. Umbi-umbian merupakan salah satu alternatif yang dapat digunakan sebagai makanan pokok bebas gluten dan mudah didapatkan di Indonesia tanpa harus mengimpor dari luar negeri. Umbi-umbian yang bisa dimanfaatkan untuk flakes adalah kentang. Menurut Niederhauser (1993) dalam Asgar (2013), kentang (Solanum tuberosum L.) merupakan salah satu umbiumbian yang banyak digunakan sebagai sumber karbohidrat atau makanan pokok bagi masyarakat dunia setelah gandum, jagung dan beras. Komposisi utama kentang terdiri atas $78 \%$ air, $19 \%$ karbohidrat, $2 \%$ protein, vitamin $\mathrm{C}$, dan vitamin B1. Umbi kentang juga mengandung beberapa mineral lain, yaitu kalsium, fosfor, zat besi, magnesium, kalium, natrium, klorin, sulfur, tembaga, mangan, dan kobalt. Kentang memiliki nilai indeks glikemik yang lebih rendah dibandingkan dengan terigu yaitu 56. Menurut Ramadhani (2016) pembuatan flakes menggunakan kentang kukus dan terigu mendapat hasil terbaik adalah pada perbandingan $70 \%$ kentang kukus dengan $30 \%$ terigu. Dalam penelitian ini kentang yang digunakan adalah kentang kukus, karena menurut senyawa pada bahan makanan seperti vitamin akan terjaga dan tidak mudah rusak ketika dikukus, sebab melibatkan uap panas yang tidak menarik senyawa vitamin yang terdapat pada bahan makanan yang justru membuat senyawasenyawa beracun seperti sianida atau cemaran pestisida keluar dari sayuran. Menurut ahli diet, Nigel Denby, mengukus bahan makanan dapat mempertahankan zat gizi hingga $82 \%$ (Anon, 2017)

Penggunaan kentang untuk flakes, sebagai produk diversifikasi pangan yang bergizi masih memiliki kekurangan yaitu rendahnya kandungan protein pada kentang, untuk memenuhi nilai gizi protein dilakukan penambahan bahan pangan yang mengandung protein tinggi, yaitu dari jenis kacang- kacangan, salah satunya adalah kacang hijau. Kacang hijau merupakan sumber protein nabati dan beberapa zat lain yang sangat bermanfaat bagi tubuh manusia seperti karbohidrat, vitamin (A, $\mathrm{B}_{1}, \mathrm{C}$ dan $\left.\mathrm{E}\right)$, besi, belerang, kalsium, lemak, mangan, magnesium dan niasin (Purwono, 2005). Kacang hijau memiliki kelebihan dibanding kacangkacangan lain, yaitu tripsin inhibitornya sangat rendah yaitu 102,28 TIU (Tripsin Inhibitor Unit)/mg, mudah dicerna dan paling kecil memberi pengaruh flatulensi atau kembung (Payumo, 1978). Berdasarkan hal tersebut maka dilakukan penelitian terhadap pemanfaatan kentang dan kacang hijau pada pembuatan flakes.

\section{METODE PENELITIAN}

\section{Tempat dan Waktu}

Penelitian ini dilaksanakan di Laboratorium Pengolahan Pangan, Laboratorium Analisis Pangan, dan Laboratorium Rekayasa Proses dan Pengendalian Mutu Fakultas Teknologi Pertanian, Universitas Udayana, Denpasar. Penelitian ini dilaksanakan dari bulan Mei 2018 sampai dengan bulan Juli 2018.

\section{Alat dan bahan \\ Alat-alat yang digunakan antara lain waskom, sendok, timbangan analitik (Methler Toledo AB-204), blender (miyako), rolling pin, loyang, kompor gas (Rinnai), oven (Blue M), muffle, pipet tetes, pipet volume, cawan porselin, tabung reaksi, labu takar (Pyrex), gelas ukur (Pyrex), gelas beker, penjepit, soxhlet, cawan lemak, pemanas listrik, penjepit labu lemak, gunting, destilator, erlenmeyer, desikator, dan labu kjeldahl. \\ Bahan-bahan yang digunakan dalam penelitian ini terdiri dari kentang jenis kentang kuning, kacang hijau jenis Vima-2, alumunium foil yang diperoleh dari Pasar Swalayan Tiara Dewata, gula halus, garam, telur, margarin, yang diperoleh di Pasar Sari Murni Denpasar, Aquadest, Tablet Kjeldahl, $\mathrm{H}_{2} \mathrm{SO}_{4}, \mathrm{NaOH}$,}


$\mathrm{HCl}$, Phenolptalein, Pelarut Heksan, dan Asam Borat.

\section{Rancangan Percobaan}

Rancangan ini menggunakan rancangan acak lengkap (RAL) dengan perlakuan perbandingan kentang kukus dan tepung kacang hijau yang terdiri dari 6 perlakuan, yaitu :

P1 $=35 \%$ kentang kukus: $65 \%$ tepung kacang hijau

P2 $=40 \%$ kentang kukus: $60 \%$ tepung kacang hijau

P3 $=45 \%$ kentang kukus: $55 \%$ tepung kacang hijau

P4=50\% kentang kukus: 50\% tepung kacang hijau

P5 $=55 \%$ kentang kukus: $45 \%$ tepung kacang hijau

P6 $=60 \%$ kentang kukus: $40 \%$ tepung kacang hijau

Perlakuan ini diulang sebanyak tiga kali sehingga diperoleh 18 unit percobaan. Data yang diperoleh dianalisis dengan sidik ragam dan apabila terdapat perbedaan nyata terhadap variabel yang diamati dilanjutkan dengan uji Duncan (Gomez dan Gomez, 1995).

\section{Pelaksanaan Penelitian}

Pelaksanaan penelitian untuk pembuatan flakes terdiri dari tiga tahap yaitu:

\section{Tahap I Pembuatan Kentang Kukus}

Kentang dicuci dengan air mengalir, dipotong menjadi 4 bagian dan dikukus pada suhu $\pm 100^{\circ} \mathrm{C}$ selama 20 menit. Kemudian kentang yang telah matang didinginkan dan dikupas kulitnya. Kentang yang sudah dikupas kulitnya kemudian dihaluskan.

\section{Tahap II Pembuatan Tepung Kacang Hijau}

Pembuatan Tepung Kacang Hijau mengikuti metode Ratnasari dan Yunianta,(2015) yang dimodifikasi sebagai berikut. Kacang hijau disortasi dan dicuci dengan air. Setelah dicuci kacang hijau kemudian dikukus pada suhu $100^{\circ} \mathrm{C}$ selama 30 menit, dikeringkan dengan oven pada suhu $60^{\circ} \mathrm{C}$ selama 8 jam. Kacang hijau yang telah kering kemudian dihaluskan dan diayak dengan ayakan 80 mesh.

\section{Tahap III Pembuatan Flakes}

Pembuatan flakes mengikuti metode Ramadhani, (2016) yang dimodifikasi sebagai berikut: Kentang kukus dicampurkan dengan tepung kacang hijau sesuai perlakuan, kemudian ditambahkan gula, garam, telur dan margarin dicampur dan diaduk sampai merata. Adonan yang sudah jadi kemudian diambil sedikit demi sedikit kemudian digiling hingga terbentuk lembaran yang tipis $( \pm 1 \mathrm{~mm})$ lalu dicetak. Flakes yang sudah dicetak tersebut kemudian dioven dengan suhu $100^{\circ} \mathrm{C}$ selama 20 menit, setelah itu dikeluarkan dari oven dan diperoleh flakes.

\section{Variabel yang diamati}

Variabel yang diamati dalam penelitian ini adalah kadar air dilakukan dengan metode pengeringan, kadar abu dilakukan dengan metode pengabuan, kadar protein dilakukan dengan metode Mikro-Kjedahl, kadar lemak dilakukan dengan metode Soxhlet (Sudarmadji et al., 1997), kadar karbohidrat dilakukan dengan metode Carbohydrate by different (AOAC., 1990), dan uji sensoris meliputi warna, rasa, aroma, tekstur dan penerimaan keseluruhan menggunakan uji hedonik serta tekstur menggunakan uji skoring (Soekarto, 1985).

Bahan yang digunakan ditimbang sesuai formula. Formula bahan flakes dapat dilihat pada Tabel 1 . 
Tabel 1. Formula flakes

\begin{tabular}{|c|c|c|c|c|c|c|}
\hline \multirow[t]{2}{*}{ Komposisi Bahan } & \multicolumn{6}{|c|}{ Perlakuan } \\
\hline & P1 & P2 & P3 & P4 & P5 & P6 \\
\hline Kentang kukus (\%) & 35 & 40 & 45 & 50 & 55 & 60 \\
\hline Tepung kacang hijau (\%) & 65 & 60 & 55 & 50 & 45 & 40 \\
\hline Gula halus $(\%)$ & 2 & 2 & 2 & 2 & 2 & 2 \\
\hline Garam (\%) & 1 & 1 & 1 & 1 & 1 & 1 \\
\hline Telur $(\%)$ & 10 & 10 & 10 & 10 & 10 & 10 \\
\hline Margarin $(\%)$ & 5 & 5 & 5 & 5 & 5 & 5 \\
\hline
\end{tabular}

Keterangan : Persentase bahan yang lain berdasarkan jumlah kentang kukus dan tepung kacang hijau (100 g).

HASIL DAN PEMBAHASAN

\section{Hasil Analisis Bahan Baku}

Hasil analisis kadar air, kadar abu, kadar protein, kadar lemak dan kadar karbohidrat dari kentang kukus dan tepung kacang hijau dapat dilihat pada Tabel 2.

Tabel 2. Nilai rata-rata Kadar Air, Kadar Abu, Kadar Protein, Kadar Lemak, dan Kadar Karbohidrat dari Kentang Kukus dan Tepung Kacang Hijau.

\begin{tabular}{lll}
\hline Komponen & Kentang kukus & Tepung Kacang Hijau \\
\hline Air $(\%)$ & 81,42 & 7,37 \\
Abu (\%) & 0,96 & 3,41 \\
Protein $(\%)$ & 2,30 & 19,93 \\
Lemak $(\%)$ & 5,39 & 9,12 \\
Karbohidrat $(\%)$ & 9,92 & 60,17 \\
\hline
\end{tabular}

Kentang kukus memiliki kadar air yaitu $81,42 \%$, kadar abu yaitu $0,96 \%$, kadar protein yaitu $2,30 \%$, kadar lemak yaitu $5,39 \%$ dan kadar karbohidrat yaitu 9,92\%. Tepung kacang hijau memiliki kadar air yaitu 7,37\%, kadar abu yaitu 3,41\%, kadar protein yaitu 19,93\%, kadar lemak yaitu $9,12 \%$ dan kadar karbohidrat yaitu $60,17 \%$. Berdasarkan Tabel 2 kadar air kentang kukus jauh lebih tinggi jika dibandingkan kadar air tepung kacang hijau, sedangkan kadar abu, kadar protein, kadar lemak dan kadar karbohidrat pada kacang hijau lebih tinggi dibandingkan dengan kentang kukus. Sesuai hal tersebut penambahan bahan tepung kacang hijau bertujuan untuk meningkatkan kandungan gizi pada flakes.

\section{Hasil Analisis Flakes}

Hasil analisis kadar air, kadar abu, kadar protein, kadar lemak dan kadar karbohidrat dari flakes dapat dilihat pada Tabel 3.

\section{Kadar Air}

Hasil sidik ragam menunjukkan bahwa perbandingan kentang kukus dengan tepung kacang hijau berpengaruh nyata $(\mathrm{P}<0,05)$ terhadap kadar air flakes. Tabel 3 menunjukkan kadar air flakes berkisar antara $2,41 \%$ sampai dengan $6,47 \%$. Kadar air flakes tertinggi diperoleh dari perlakuan P6 (60\% kentang kukus : 40\% tepung kacang hijau) yaitu $6,47 \%$ dan berbeda tidak nyata dengan P4 dan P5, sedangkan kadar air flakes terendah diperoleh dari perlakuan P1 (35\% kentang kukus : $65 \%$ tepung kacang hijau) yaitu sebesar $2,41 \%$.

Penurunan kadar air terjadi seiring meningkatnya penambahan tepung kacang hijau, hal ini disebabkan karena kadar air tepung kacang hijau lebih rendah dibandingkan kadar air kentang kukus. Kadar air tepung kacang hijau adalah 7,37\% sedangkan kadar air kentang kukus adalah $81,42 \%$. Nilai kadar air menururt SNI flakes maksimal 3\% (Anon., 1996), jadi kadar air 
flakes yang dihasilkan untuk P1 memenuhi SNI flakes dan P2 sampai P6 tidak memenuhi SNI flakes.

\section{Kadar Abu}

Hasil sidik ragam menunjukkan bahwa perbandingan kentang kukus dengan tepung kacang hijau berpengaruh tidak nyata terhadap kadar abu flakes. Tabel 3 menunjukkan kadar abu flakes berkisar antara 4,56\% sampai dengan $4,84 \%$. Kadar abu dipengaruhi oleh kandungan mineral pada bahan baku dalam pembuatan flakes. Tingginya kandungan mineral pada kacang hijau mengakibatkan flakes yang dihasilkan memiliki kadar abu yang tinggi. Nilai kadar abu menururt SNI flakes maksimal 4\% (Anon., 1996), jadi kadar abu flakes yang dihasilkan tidak memenuhi SNI flakes. Nilai kadar abu menururt SNI flakes maksimal 4\% (Anon., 1996), jadi kadar abu flakes yang dihasilkan tidak memenuhi SNI flakes.

Tabel 3. Nilai rata-rata kadar air, kadar abu, kadar protein, kadar lemak, dan kadar karbohidrat flakes.

\begin{tabular}{lccccc}
\hline $\begin{array}{c}\text { Perlakuan } \\
\text { KK:KH }(\%)\end{array}$ & $\begin{array}{c}\text { Kadar air } \\
(\%)\end{array}$ & Kadar abu (\%) & $\begin{array}{c}\text { Kadar protein } \\
(\%)\end{array}$ & $\begin{array}{c}\text { Kadar lemak (\%) } \\
\text { Kadar karbohidrat } \\
(\%)\end{array}$ \\
\hline P1 $(35: 65)$ & $2,41 \pm 0,19 \mathrm{c}$ & $4,57 \pm 0,15 \mathrm{a}$ & $19,16 \pm 0,89 \mathrm{a}$ & $10,20 \pm 0,95 \mathrm{a}$ & $63,66 \pm 0,45 \mathrm{a}$ \\
P2 $(40: 60)$ & $4,26 \pm 0,66 \mathrm{~b}$ & $4,66 \pm 0,52 \mathrm{a}$ & $19,12 \pm 0,49 \mathrm{a}$ & $8,91 \pm 0,11 \mathrm{~b}$ & $63,05 \pm 0,11 \mathrm{a}$ \\
P3 (45:55) & $4,96 \pm 0,61 \mathrm{~b}$ & $4,56 \pm 0,32 \mathrm{a}$ & $19,10 \pm 0,52 \mathrm{a}$ & $8,49 \pm 0,25 \mathrm{~b}$ & $62,89 \pm 0,61 \mathrm{a}$ \\
P4 (50:50) & $6,20 \pm 0,75 \mathrm{a}$ & $4,67 \pm 0,15 \mathrm{a}$ & $17,99 \pm 0,38 \mathrm{~b}$ & $8,39 \pm 0,06 \mathrm{~b}$ & $62,75 \pm 0,78 \mathrm{a}$ \\
P5 (55:45) & $6,29 \pm 0,65 \mathrm{a}$ & $4,67 \pm 0,18 \mathrm{a}$ & $17,93 \pm 0,37 \mathrm{~b}$ & $8,37 \pm 0,58 \mathrm{~b}$ & $62,75 \pm 0,52 \mathrm{a}$ \\
P6 (60:40) & $6,47 \pm 0,25 \mathrm{a}$ & $4,84 \pm 0,11 \mathrm{a}$ & $17,82 \pm 0,66 \mathrm{~b}$ & $8,27 \pm 0,12 \mathrm{~b}$ & $62,60 \pm 0,74 \mathrm{a}$ \\
\hline
\end{tabular}

Keterangan : Nilai rata-rata yang diikuti oleh huruf yang berbeda pada kolom yang sama menunjukkan berbeda nyata $(\mathrm{P}<0,05)$.

$\mathrm{KK}=$ Kentang Kukus

$\mathrm{KH}=$ Tepung Kacang Hijau

\section{Kadar Protein}

Hasil sidik ragam menunjukkan bahwa perbandingan kentang kukus dengan tepung kacang hijau berpengaruh nyata $(\mathrm{P}<0,05)$ terhadap kadar protein flakes. Tabel 3 menunjukkan kadar protein flakes berkisar antara $17,82 \%$ sampai dengan $19,16 \%$. Kadar protein flakes tertinggi diperoleh dari perlakuan P1 yaitu 19,16\% dan berbeda tidak nyata dengan $\mathrm{P} 2$ dan $\mathrm{P} 3$, sedangkan kadar protein flakes terendah diperoleh dari perlakuan P6 yaitu sebesar 17,82\% dan berbeda tidak nyata dengan P4 dan P5.

Penurunan kadar protein terjadi seiring meningkatnya penambahan kentang kukus, hal ini disebabkan karena kadar protein kentang kukus lebih rendah dibandingkan kadar protein tepung kacang hijau. Kadar protein kentang kukus adalah 2,30\% sedangkan kadar protein tepung kacang hijau adalah 19,93\%. Nilai kadar protein menururt SNI flakes minimal 5\%
(Anon., 1996), jadi kadar protein flakes yang dihasilkan untuk P1 sampai dengan P6 memenuhi SNI flakes.

\section{Kadar Lemak}

Hasil sidik ragam menunjukkan bahwa perbandingan kentang kukus dengan tepung kacang hijau berpengaruh nyata $(\mathrm{P}<0,05)$ terhadap kadar lemak flakes. Tabel 3 menunjukkan kadar lemak flakes berkisar antara 8,27\% sampai dengan 10,20\%. Kadar lemak flakes tertinggi diperoleh dari perlakuan P1 yaitu 10,20\%, sedangkan kadar lemak flakes terendah diperoleh dari perlakuan P6 yaitu sebesar $8,27 \%$ dan berbeda tidak nyata dengan P2, P3, P4, P5, dan P6.

Penurunan kadar lemak terjadi seiring meningkatnya penambahan kentang kukus, hal ini disebabkan karena kadar lemak kentang kukus lebih rendah dibandingkan kadar lemak tepung kacang hijau. Kadar lemak tepung 
kacang hijau adalah 9,12\% sedangkan kadar lemak kentang kukus adalah 5,39\%. Nilai kadar lemak menururt SNI flakes minimal 7\% (Anon., 1996), jadi kadar lemak flakes yang dihasilkan untuk P1 sampai dengan P6 memenuhi SNI flakes.

\section{Kadar Karbohidrat}

Hasil sidik ragam menunjukkan bahwa perbandingan kentang kukus dengan tepung kacang hijau berpengaruh tidak nyata terhadap kadar karbohidrat flakes. Tabel 3 menunjukkan kadar karbohidrat flakes berkisar antara $62,60 \%$ sampai dengan $63,66 \%$. Nilai kadar karbohidrat menururt SNI flakes minimal
60,7\% (Anon., 1996), jadi kadar karbohidrat flakes yang dihasilkan untuk P1 sampai dengan P6 memenuhi SNI flakes.

\section{Uji Sensoris}

Uji sensoris flakes dilakukan dengan uji hedonik terhadap warna, aroma, tekstur, rasa dan penerimaan keseluruhan. Uji skoring dilakukan terhadap tekstur flakes. Nilai ratarata uji hedonik terhadap warna, aroma, tekstur, rasa dan penerimaan keseluruhan flakes dapat dilihat pada Tabel 4. Nilai ratarata uji skoring terhadap tekstur flakes dapat dilihat pada Tabel 5.

Tabel 4. Nilai rata-rata uji hedonik terhadap warna, aroma, tekstur, rasa dan penerimaan keseluruhan flakes

\begin{tabular}{cccccc}
\hline Perlakuan & \multicolumn{5}{c}{ Nilai rata-rata uji hedonik } \\
KK:KH $(\%)$ & Warna & Aroma & Tekstur & Rasa & $\begin{array}{c}\text { Penerimaan } \\
\text { keseluruhan }\end{array}$ \\
& & & & & \\
& & & & \\
P1(35:65) & $5,85 \pm 0,81 \mathrm{a}$ & $5,80 \pm 0,95 \mathrm{a}$ & $6,25 \pm 0,55 \mathrm{a}$ & $4,15 \pm 0,93 \mathrm{c}$ & $5,50 \pm 0,89 \mathrm{a}$ \\
P2(40:60) & $5,70 \pm 0,80 \mathrm{ab}$ & $5,30 \pm 0,80 \mathrm{ab}$ & $5,95 \pm 0,51 \mathrm{ab}$ & $4,75 \pm 0,79 \mathrm{~b}$ & $5,20 \pm 0,89 \mathrm{ab}$ \\
P3(45:55) & $5,20 \pm 0,95 \mathrm{~b}$ & $4,95 \pm 0,83 \mathrm{~b}$ & $5,50 \pm 0,69 \mathrm{bc}$ & $5,15 \pm 0,81 \mathrm{ab}$ & $5,05 \pm 0,83 \mathrm{ab}$ \\
P4(50:50) & $4,60 \pm 0,99 \mathrm{c}$ & $4,45 \pm 0,69 \mathrm{bc}$ & $5,10 \pm 0,72 \mathrm{~cd}$ & $4,60 \pm 0,99 \mathrm{bc}$ & $4,90 \pm 0,79 \mathrm{ab}$ \\
P5(55:45) & $4,20 \pm 0,95 \mathrm{~cd}$ & $4,40 \pm 0,82 \mathrm{bc}$ & $4,95 \pm 0,99 \mathrm{~d}$ & $4,90 \pm 0,97 \mathrm{~b}$ & $4,85 \pm 0,99 \mathrm{~b}$ \\
P6(60:40) & $3,85 \pm 0,99 \mathrm{~d}$ & $4,30 \pm 0,98 \mathrm{~d}$ & $4,80 \pm 0,77 \mathrm{~d}$ & $5,60 \pm 0,94 \mathrm{a}$ & $4,70 \pm 0,98 \mathrm{~b}$ \\
\hline
\end{tabular}

Keterangan : Nilai rata-rata yang diikuti oleh huruf yang berbeda pada kolom yang sama menunjukkan berbeda nyata $(\mathrm{P}<0,05)$.

\section{Warna}

Hasil sidik ragam menunjukkan bahwa perbandingan kentang kukus dengan tepung kacang hijau berpengaruh nyata $(\mathrm{P}<0,05)$ terhadap warna (uji hedonik) flakes. Tabel 4 menunjukkan bahwa nilai rata-rata tertinggi diperoleh dari flakes dari perlakuan P1 yaitu suka dan berbeda tidak nyata dengan P2, sedangkan nilai terendah diperoleh dari flakes pada perlakuan P6 yaitu biasa dan berbeda tidak nyata dengan P5. Berdasarkan uji hedonik kesukaan panelis semakin meningkat seiring dengan meningkatnya konsentrasi tepung kacang hijau.

Menurut Winarno (2004) warna merupakan komponen yang sangat penting untuk menentukan kualitas atau derajat penerimaan suatu bahan pangan. Suatu bahan pangan meskipun dinilai enak dan teksturnya baik, tetapi jika memiliki warna yang tidak menarik atau memberi kesan yang menyimpang dari warna yang seharusnya maka bahan tersebut tidak akan dikonsumsi. Penentuan mutu suatu bahan pangan pada umumnya tergantung pada warna karena warna penilaian pertama suatu produk. 
Tabel 5. Nilai rata-rata uji skoring terhadap tekstur flakes

\begin{tabular}{cc} 
Perlakuan & Nilai rata-rata uji skoring \\
KK:KH (\%) & Tekstur \\
\hline P1 (35:65) & $4,35 \pm 0,75 \mathrm{a}$ \\
P2 (40:60) & $3,80 \pm 0,77 \mathrm{~b}$ \\
P3 (45:55) & $3,60 \pm 0,68 \mathrm{bc}$ \\
P4 (50:50) & $3,40 \pm 0,68 \mathrm{bcd}$ \\
P5 (55:45) & $3,20 \pm 0,70 \mathrm{~cd}$ \\
P6 (60:40) & $2,95 \pm 0,69 \mathrm{~d}$ \\
\hline
\end{tabular}

Keterangan : Nilai rata-rata yang diikuti oleh huruf yang berbeda pada kolom yang sama menunjukkan berbeda nyata $(\mathrm{P}<0,05)$

\section{Aroma}

Hasil sidik ragam menunjukkan bahwa perbandingan kentang kukus dengan tepung kacang hijau berpengaruh nyata $(\mathrm{P}<0,05)$ terhadap aroma (uji hedonik) flakes. Tabel 4 menunjukkan bahwa nilai rata-rata tertinggi diperoleh dari flakes dari perlakuan P1 yaitu suka dan berbeda tidak nyata dengan P2, sedangkan nilai terendah diperoleh dari flakes pada perlakuan P6 yaitu biasa. Berdasarkan uji hedonik kesukaan panelis semakin meningkat seiring dengan meningkatnya konsentrasi tepung kacang hijau.

\section{Tekstur}

Hasil sidik ragam menunjukkan bahwa perbandingan kentang kukus dengan tepung kacang hijau berpengaruh nyata $(\mathrm{P}<0,05)$ terhadap tekstur (uji hedonik) flakes. Tabel 4 menunjukkan bahwa nilai rata-rata tertinggi diperoleh dari flakes dari perlakuan P1 yaitu suka dan berbeda tidak nyata dengan P2, sedangkan nilai terendah diperoleh dari flakes pada perlakuan P6 yaitu agak suka dan berbeda tidak nyata dengan P4 dan P5.

Hasil sidik ragam menunjukkan bahwa perbandingan kentang kukus dengan tepung kacang hijau berpengaruh nyata $(\mathrm{P}<0,05)$ terhadap tekstur (uji skoring) flakes. Tabel 12 menunjukkan bahwa nilai rata-rata tertinggi diperoleh dari flakes dari perlakuan P1 yaitu renyah, sedangkan nilai terendah diperoleh dari flakes pada perlakuan P6 yaitu agak renyah dan berbeda tidak nyata dengan $\mathrm{P} 4$ dan
P5. Tekstur renyah pada flakes dipengaruhi oleh kadar air dari flakes, dimana semakin banyak penambahan tepung kacang hijau maka semakin rendah kadar air dari flakes yang dihasilkan. Semakin rendah kadar air flakes yang dihasilkan maka semakin renyah tekstur yang dihasilkan. Panelis menyukai tekstur pada perlakuan P1 dengan kriteria renyah.

\section{Rasa}

Hasil sidik ragam menunjukkan bahwa perbandingan kentang kukus dengan tepung kacang hijau berpengaruh nyata $(\mathrm{P}<0,05)$ terhadap rasa (uji hedonik) flakes. Tabel 4 menunjukkan bahwa nilai rata-rata tertinggi diperoleh dari flakes dari perlakuan P6 yaitu suka dan berbeda tidak nyata denga P3, sedangkan nilai terendah diperoleh dari flakes pada perlakuan P1 yaitu biasa.

\section{Penerimaan Keseluruhan}

Hasil sidik ragam menunjukkan bahwa perbandingan kentang kukus dengan tepung kacang hijau berpengaruh nyata $(\mathrm{P}<0,05)$ terhadap penerimaan keseluruhan (uji hedonik) flakes. Tabel 4 menunjukkan bahwa nilai ratarata tertinggi diperoleh dari flakes dari perlakuan P1 yaitu agak suka dan berbeda tidak nyata dengan $\mathrm{P} 2$, P3 dan $\mathrm{P} 4$, sedangkan nilai terendah diperoleh dari flakes pada perlakuan P6 yaitu agak suka dan berbeda tidak nyata dengan P2, P3, P4 dan P5. Penerimaan keseluruhan dipengaruhi oleh 
beberapa faktor seperti warna, aroma, tekstur dan rasa.

\section{KESIMPULAN DAN SARAN}

\section{Simpulan}

Berdasarkan hasil penelitian ini dapat disimpulkan sebagai berikut :

1. Perbandingan kentang kukus dan tepung kacang hijau berpengaruh nyata terhadap kadar air, kadar protein, kadar lemak, uji hedonik terhadap warna, aroma, tekstur, rasa dan penerimaan keseluruhan dan tekstur flakes (uji scoring)

2. Perbandingan 35\% kentang kukus : $65 \%$ tepung kacang hijau menghasilkan flakes dengan karakteristik terbaik yaitu kadar air $2,41 \%$, kadar abu 4,57\%, kadar protein $19,16 \%$, kadar lemak 10,20\%, kadar karbohidrat $63,66 \%$, warna suka, aroma suka, tekstur renyah dan suka, rasa biasa, penerimaan keseluruhan agak suka.

\section{Saran}

Berdasarkan hasil penelitian ini disarankan untuk menggunakan perbandingan $35 \%$ kentang kukus : $65 \%$ tepung kacang hijau dalam proses pembuatan flakes.

\section{DAFTAR PUSTAKA}

Anonimus. 1996. SNI 01-4270-1996. Syarat Mutu Sereal. Jakarta. Badan Standarisasi Nasional.

Anonimus. 2017. Health \& Diet. http://www.femina.co.id. Diakses pada tanggal 26 Oktober 2018

AOAC. 1990. Official Methods of Analysis of The Association of Agriculture Chemist A.O.A.C, Washington D.C.

Asgar, A. 2013. Umbi kentang (Solanum tuberosum L.) klon 395195.7 dan CIP 394613.32 yang ditanam di dataran medium mempunyai harapan untuk keripik. Iptek Hortikultura. (9) : 32-35.

Gomez, K. A. dan A. A. Gomez. 1995. Prosedur Statistik Untuk Penelitian Pertanian. UI Press. Jakarta.

Papunas, M.E., G.S.S. Djarkasi., dan J.S.C. Moningka. 2013. Karakteristik fisikokimia dan sensoris flakes berbahan baku tepung jagung (Zea mays L), tepung pisang goroho (Musa acuminafe,sp) dan tepung kacang hijau (Phaseolus radiatus). Jurnal Ilmu dan Teknologi Pangan Unsrat.Vol. 3 No. 5.

Paramita, A H dan W.D.R Putri. 2015. Pengaruh penambahan tepung bengkuang dan lama pengukusan terhadap karakteristik fisik, kimia dan organoleptik flake talas. Jurnal Pangan dan Agroindustri. 3 (3): 1071-1082

Payumo, E.M. 1978. The Potensials of Mungbean as a Protein Suplement for Child Feeding. Dalam: The $1^{\text {st }}$ International Mungbean Symposium. Unido.

Purwono dan R. Hartono. 2005. Kacang Hijau. Penebar Swadaya, Depok.

Ramadhani K.A., N.W. Wisaniyasa., dan P.A. Sandhi W. 2016. Pengaruh perbandingan kentang kukus dengan terigu terhadap karakteristik flakes. Jurnal Ilmu dan Teknologi Pangan. 5 (1):1-10.

Soekarto, S.T. 1985. Penilaian Organoleptik Untuk Industri Pangan dan Pertanian. Bharata Karya Aksara. Jakarta.

Sudarmadji, S. B. Haryono dan Suhardi. 1997. Prosedur Analisa Untuk Bahan Makanan dan Pertanian Edisi Keempat. Liberty. Yogyakarta.

Winarno, F.G. 2004. Hasil-hasil Simposium 
Penganekaragaman Pangan. Prakarsa

Swasta dan Pemda, Jakarta 